\title{
The Attractiveness of Poland as a Medical Tourism Destination from the Perspective of German and British Consumers
}

\author{
Diana Dryglas, Adrian Lubowiecki-Vikuk
}

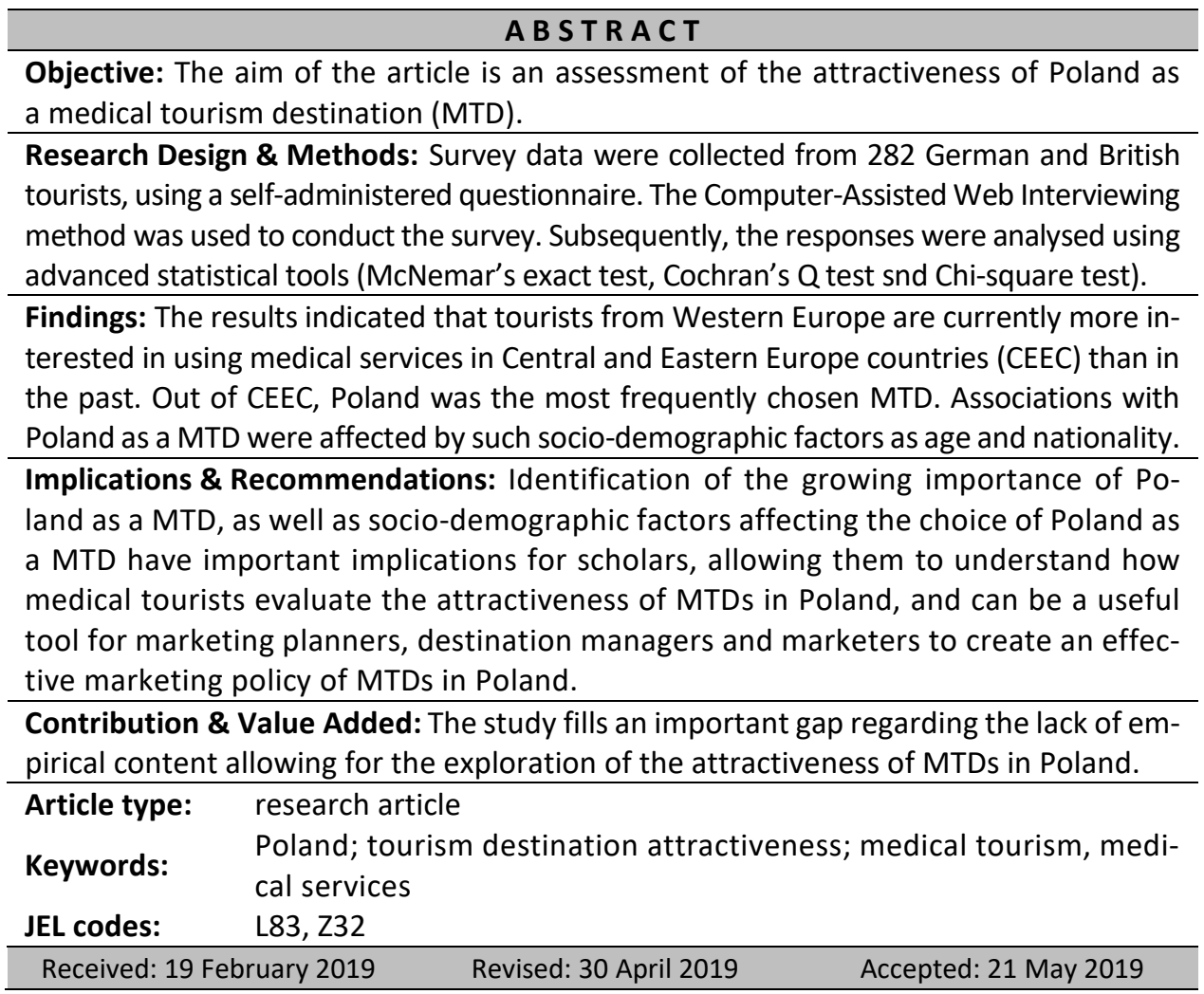

\section{Suggested citation:}

Dryglas, D., \& Lubowiecki-Vikuk, A. (2019). The Attractiveness of Poland as a Medical Tourism Destination from the Perspective of German and British Consumers. Entrepreneurial Business and Economics Review, 7(2), 45-62. https://doi.org/10.15678/EBER.2019.070203 


\section{INTRODUCTION}

Since the late 1990s - mainly because of mass media (television, the Internet, the press) and the tourism industry - medical tourism has gained momentum (Connell, 2016). This trend stems from 'changes in demographics, today's education, standard of living, social behaviour, and lifestyle' (Breitrück \& Nunn, 2011, p. 57; Stankova, Tsvetkov, \& Ivanova, 2019). Medical tourism should be perceived as a phenomenon in which patients travel outside their permanent place of residence to use health-related services, including tourism packages (Connell, 2013). It is a growing phenomenon spurred on by an increasingly empowered patient base searching for quality, affordability, availability, accessibility in healthcare, perceived quality, satisfaction, and trust in the staff and clinic, and attractiveness of a tourism destination (Choi, 2016; Connell, 2013), including access to treatments that are not legally allowed in the place of residence (Dryglas, 2018). The reasons why patients undertake medical trips also include a feeling of overall dissatisfaction with the national health system, or even the need to preserve confidentiality for some people seeking medical treatment (Cameron, Crooks, Chouinard, Snyder, Johnston, \& Casey, 2014). As reported by Gupte and Panjamapirom (2014), the number of medical tourists increased from approximately 10.5 million in 2011 to 23.2 million in 2017, and generated global revenue of approximately USD 40-60 billion. For instance, in South Korea alone, medical tourism revenue in 2017 amounted to USD 15 billion and is predicted to reach USD 20 billion by 2022 (South Korea medical tourism market: Insights, opportunity, analysis, market shares and forecast 2017-2022, 2018). Nonetheless, according to Beladi, Chao, Ee and Hollas (2015), the output contribution of medical tourism is overestimated by an average of $26.8 \%$.

In the field of science and social life, medical tourism is still not fully recognised or clearly defined (Connell, 2013). Various approaches are adopted in literature to explain this phenomenon, and thus the concept of medical tourism is still unstable. According to Connell, any medically-motivated cross-border mobility should be referred to as medical travel, 'but it should also be noted that 'medical tourism' will continue to be used for many components of that mobility' (Connell, 2013, p. 10).

Medical tourism is a complex process, resulting from the requirements of the modern market, particularly in terms of demand (Runnels \& Carrera, 2012). The medical tourism market understood as 'the entirety of service-financial exchange relations between the provider (medical and tourism sector entity) and the beneficiary (medical tourist), occurring outside of the latter's place of permanent residence, who finances (or co-finances) the process of purchasing a package of services, which brings benefits to both sides' (Lubowiecki-Vikuk \& Rab-Przybyłowicz, 2015, p. 87), is extensive and internally complex. This stems from a specific relation, namely an interdependent exchange taking place between providers and purchasers of both medical and tourism services, and paramedical and paratourism services (Heung, Kucukusta, \& Song, 2010). This, in turn, necessitates interdisciplinary market research, including scientific studies, as a status quo from the medical and tourism point of view (Freyer \& Kim, 2014). The medical tourism destination (MTD) applies to specific areas, i.e. countries, regions, cities and metropolitan areas (Ghanbari, Hajinejad, \& Rahmani, 2014; Ormond \& Kaspar, 2019), where the medical tourism product is offered, in other words prepared for sale as a package offer consisting of medical and tourism services, the basis for 
which is set by the presence of clinics and private providers of medical services (RabPrzybyłowicz, 2016). Nowadays, there are numerous countries which constitute MTDs, especially Asian countries (e.g. Singapore, India, Thailand, Malaysia, South Korea), the U.S., Mexico, countries of the Middle and South America (e.g. Crooks, Turner, Snyder, Johnston, \& Kingsbury, 2011; Fetscherin \& Stephano, 2016; Guiry \& Vequist, 2015; Junio, Kim, \& Lee, 2017; Mahendradhata, 2019). The remaining MTDs are still difficult to reach, especially the Balkan countries (Kiss, 2015) and Central and Eastern Europe countries (CEEC), where Poland is considered one of the MTD leaders in this part of Europe (Fetscherin \& Stephano, 2016; Mainil, Eijgelaar, Klijs, Nawijn, \& Peeters, 2017). Unlike in Asian countries and Western Europe, where the emphasis is put on prevention, mental and physical health, in CEEC the emphasis is primarily placed on physical health (Smith \& Puczkó, 2014).

Extensive research into the phenomenon of MTDs conducted mainly in Asian MTDs and Western Europe (de la Hoz-Correa, Muñoz-Leiva, \& Bakucz, 2018; Guiry \& Veguist, 2015; Lu \& Wu, 2018), strikingly reflects the fragmentary nature of scientific knowledge about this subject in CEEC. The above-mentioned studies focus on the analysis of risks, barriers and factors attracting foreign patients to a given destination (country, centre). Furthermore, Zarei and Maleki (2019) demonstrated that the perceived quality of medical services and patient satisfaction are the most important factors that attract medical tourists. What is also important are lower service costs and shorter wait time, which depend on the complexity and invasiveness of a given medical procedure (Connell, 2013). On the other hand, the authors state that the cooperation of entities offering medical services, the already mentioned quality of these services, insurance and legal provisions constitute the main barriers to the decision on having treatment abroad. A study by Sziva, Balázs, Michalkó, Kiss, Puczkó, Smith and Apró (2017) demonstrates that the potential of MTDs in CEEC has not been fully exploited. Therefore, the aim of the article is an empirical verification of the attractiveness of MTDs in Poland.

The contribution of this research is twofold. First, it provides an overview of MTD attractiveness in literature on medical tourism. Second, the empirical part of the study fills an important gap regarding the lack of empirical content allowing for the exploration of the attractiveness of MTDs in Poland. The study serves as a springboard for a discussion on the attractiveness of MTDs in Poland as perceived by foreign medical tourists. Hence, the study provides a thorough exploration of MTD attractiveness and its better understanding in CEEC through the analysis of Poland.

\section{LITERATURE REVIEW}

Mayo and Jarvis (1981) define destination attractiveness as 'the relative importance of individual benefits and the perceived ability of the destination to deliver these individual benefits' (Mayo \& Jarvis, 1981, p. 201). Only few attempts have been made to identify the attributes that medical tourists consider as important in evaluating the attractiveness of MTD and to investigate the contribution of MTD attributes to MTD attractiveness. A review of literature suggests that MTDs are multiattribute and thus the identification of the various categories of these attributes becomes important. According to Dryglas and Salamaga (2018), the existence of a MTD does not require natural resources but only particular political and legal regulations (e.g. provisions on abortion or transplantation), as well as medical infrastructure (a clinic or hospital). However, the perception of a MTD as a place with natural and cultural 
attractions and a climate differing from those found at one's place of residence contributes to the formation of MTD attractiveness. The MTD attractiveness is primarily formed by medical treatments and services, destination attributes, and tourism-specific factors (Junio, Kim, \& Lee, 2017). The research conducted by Lu and Wu (2015) clearly shows that medical tourists felt that higher service quality led to better corporate image of medical institutions, which was reflected in positive influences on the perceived value of MTD. With reference to the destination components of UNWTO (2007), Pollard (2012) distinguished seven criterions of MTD attractiveness: destination image ('place myths'), risk and reward (outcome, guarantee, track record, safety), geographical proximity (travel convenience - access and barriers, travel time), infrastructure (support services, internal travel, accommodation), cultural proximity (language, food, customs and practices, religion), destination environment (climate, facilities, tourism attractions), and price (cost of stay, insurance, cost of treatment, cost of travel). What constitutes the MTD attractiveness is, among other things: favorable climate, beautiful and often pristine natural environment, convenient location in Europe and competitive and sometimes relatively low prices for international medical tourists (Kiss, 2015; Smith \& Puczkó, 2014). This part of Europe is not only touristically attractive, but also innovative as for the access to technological medical specialisations (Wisla \& Sierotowicz, 2016). Yet, the number of tourist agencies specialising in medical tourism is growing in CEEC (Dryglas, 2018; Smith, Puczkó, Michalkó, Kiss, \& Sziva, 2016). It is crucial since according to Hemdi, Hassan, Aminuddin and Adanan (2016) as well as Idrus, Musa, Naziman, Aznan, Othman and Pauzi (2012) MTD attractiveness will positively and significantly influence a future choice of a MTD. This study extends prior studies through categorising the attributes of MTD attractiveness into medical and tourism characteristics (Table 1). Based on the literature of the subject, medical and tourism attributes that constitute MTD attractiveness can be divided into: (1) economic factors (lower costs of treatment abroad, the economic development of enterprises, country/region development), (2) cultural and social factors (the need to preserve confidentiality for some people seeking medical treatment), (3) organisationallegal factors (avoiding queues, access to medical procedures that are illegal in the patient's country of origin, effective marketing representatives of medical facilities, the ability to refund part of the cost of treatment), (4) technological factors (a high standard of medical care using state-of-the-art equipment), (5) spatial factors (travel distance), (6) natural factors (e.g. favourable climate) (Chew \& Koeshendro, 2015; Connell, 2013; Fetscherin \& Stephano, 2016; Ganguli \& Ebrahim, 2017; Lubowiecki-Vikuk, 2018; Lubowiecki-Vikuk \& Gnusowski, 2016; Lunt, Smith, Mannion, Green, Exworthy, Hanefeld, \& et al., 2014).

However, negative characteristics may significantly limit the possibilities of MTD image development in a given CEEC. This is particularly visible in MTDs of CEEC which, on the one hand, have the potential of being perceived as attractive but, on the other, are not well known among potential medical tourists who base their associations on unfavorable stereotypes rather than on facts. Stereotypes are very common in the medical tourism market. In the context of CEEC, potential medical tourists are aware that such countries exist but they know little of the medical tourism product offered there. Thus, the problem of the country image can be a barrier to the development of MTD despite its attractiveness. An example of such a destructive influence of image on MTD development is the position of CEEC in the international market of medical tourism. Developing countries constitute a good example here because they are perceived as countries with low-quality services and skills of doctors, which in turn leads 
to scepticism among patients (Borek, 2013). Therefore, Crooks et al. (2011) are right when they claim that such countries need to portray safe and advanced treatment facilities in order to dispel the potential patients' suspicions that their medical care is of lower quality. Macedonia sets a good example of a country which is planning to offer subsidies and tax breaks to foreign hospitals setting up facilities for treating private and foreign patients in a bid to improve its image as an MTD (Smith et al., 2016). However, the medical tourism market in CEEC is growing at the rate of approximately $12-15 \%$ per year. The value of the international patient market in CEEC is estimated at more than USD 100 million, representing the average rate of about 26,500 hospital patients a year, 6-8,000 of whom are treated in Poland. While the concept of choosing an MTD in Western Europe and Asian countries (e.g. de la Hoz-Correa et al., 2018) has been extensively examined in the medical tourism literature, there have been no studies that would attempt to assess CEEC, including the attractiveness of Poland's MTDs.

Table 1. Medical and tourist attributes of MTD attractiveness

\begin{tabular}{|c|c|c|}
\hline \multicolumn{2}{|r|}{ Attributes } & Authors \\
\hline \multirow{5}{*}{$\frac{\bar{\pi}}{\bar{c}}$} & $\begin{array}{l}\text { Spatial factors: innovative medical infrastruc- } \\
\text { ture, development of commercial medical fa- } \\
\text { cilities. }\end{array}$ & $\begin{array}{l}\text { Dryglas \& Salamaga (2018); Ormond, Wong, \& } \\
\text { Chan (2014); Wisla \& Sierotowicz (2016). }\end{array}$ \\
\hline & $\begin{array}{l}\text { Cultural and social factors: language, number } \\
\text { of physicians, nurses and dentists and their } \\
\text { medical competences, availability of high- } \\
\text { quality medical professionals and accredited } \\
\text { clinics or hospitals. }\end{array}$ & $\begin{array}{l}\text { Koggalage, Gunawardena, \& de Silva (2017); } \\
\text { Lubowiecki-Vikuk \& Gnusowski (2016); } \\
\text { Lubowiecki-Vikuk \& Kurkowiak (2017); Mahen- } \\
\text { dradhata (2019); Zhang, Seo, \& Lee (2013). }\end{array}$ \\
\hline & $\begin{array}{l}\text { Technological factors: quality or faster access } \\
\text { to treatments and new therapies. }\end{array}$ & $\begin{array}{l}\text { Connell (2013); Fetscherin \& Stephano (2016); } \\
\text { Hopkins, Labonte, Runnels, \& Packer (2010); } \\
\text { Junio, Kim, \& Lee (2017); Lunt et al. (2014); } \\
\text { Tham (2018); Wang (2012). }\end{array}$ \\
\hline & $\begin{array}{l}\text { Organisational-legal factors: liberalisation in } \\
\text { health care systems, a combination of indus- } \\
\text { try-specific management strategies which fa- } \\
\text { cilitate effective public-private partnerships, } \\
\text { reinvent healthcare legislation and encourage } \\
\text { investment in medical tourism infrastructure, } \\
\text { informal economies and social care networks. }\end{array}$ & $\begin{array}{l}\text { Dryglas \& Salamaga (2018); Ebrahim \& Ganguli } \\
\text { (2017); Johnston, Crooks, Snyder, \& Kingsbury } \\
\text { (2010); Ormond \& Sulianti (2017); Ried \& Mar- } \\
\text { schall (2016); Zhang, Seo, \& Lee (2013). }\end{array}$ \\
\hline & Economic factors: cost. & $\begin{array}{l}\text { Connell (2013); Fetscherin \& Stephano (2016); } \\
\text { Lubowiecki-Vikuk (2018); Lubowiecki-Vikuk \& } \\
\text { Kurkowiak (2017); Lunt et al. (2014); Pollard } \\
\text { (2012); Smith, Mannion, Green, Exworthy, } \\
\text { Hanefeld \& et al. (2014); Zhang et al. (2013). }\end{array}$ \\
\hline \multirow{3}{*}{$\frac{\grave{n}}{\frac{n}{3}}$} & Natural factors: climate, natural resources. & Dryglas (2018); Dryglas \& Salamaga $(2017,2018)$ \\
\hline & $\begin{array}{l}\text { Organisational-legal factors: access to broker } \\
\text { of medical tourism and tourist agencies spe- } \\
\text { cialising in medical tourism. }\end{array}$ & $\begin{array}{l}\text { Casey, Crooks, Snyder, \& Turner (2013); Dryglas } \\
\text { (2018); Heung, Kucukusta, \& Song (2010); Smith } \\
\text { et al. (2016); Tham (2018). }\end{array}$ \\
\hline & Spatial factors: tourist attractions. & $\begin{array}{l}\text { Connell (2013); Fetscherin \& Stephano (2016); } \\
\text { Kiss (2015); Lubowiecki-Vikuk \& Kurkowiak } \\
\text { (2017); Pollard (2012); Rab-Przybyłowicz (2016); } \\
\text { Smith \& Puczkó (2014). }\end{array}$ \\
\hline
\end{tabular}

Source: own study. 
Consequently, this gap in the literature led to the following hypothesis:

H1: The number of Britons and Germans interested in medical services provided outside their countries who would like to use medical services in CEEC is greater than the number of people who have already used such services in CEEC.

The data for 2009 indicate that foreign patients spent approx. USD 200 million on medical tourism services in Poland. Two years later, there was an increase by almost $20 \%$ (OECD, 2014). As reported by Rab-Przybyłowicz (2016), in 2015 most of the tourismrelated spending in Poland was generated by foreign tourists who visited the country for health/medical reasons. An average tourist spent around USD 490 per day/per person compared to USD 742 per day/per person spent by a medical tourist. Unfortunately, the size of the Polish medical tourism market has not been estimated yet due to the lack of fully reliable scientific research. The statistical data available are most often constructed rather intuitively, based on individual regional data, drawing on the analyses of the global medical tourism industry (Connell, 2016). The medical tourism in Poland is related in particular to private providers of medical services. For this reason, the overall assessment of the healthcare system quality published periodically by the WHO and the OECD which regards the dominant public sector in Poland may not reflect a better quality and standards of healthcare provided by private health centres used by foreign patients (Borek, 2013 , p. 342). It should also be taken into account that the rankings of the quality and accessibility of healthcare which are widely available to foreign patients are unfavourable for Poland. Apart from that, no systematic analysis of the data concerning the quality, efficiency and availability of medical care provided by private centres has been conducted yet. In the years 2011-14, the medical tourism market in Poland was dominated by Polish citizens, and every third and every fifth medical tourist came from the UK and Germany, respectively (Lubowiecki-Vikuk \& Rab-Przybyłowicz, 2015). For medical purposes, Poland was also visited by citizens of Ireland, the USA, the Netherlands, Norway, Denmark and Sweden. Apart from the EU citizens, there appeared a segment of tourists from the Commonwealth of Independent States and the Persian Gulf. Over 40,500 foreign patients (mainly males) used the services of pharmacies in southern Poland in the year 2014. They came from the UK, Germany, Russia, the Czech Republic and, less frequently, from Asian countries (Lubowiecki-Vikuk \& Mucha, 2015). In Poland medical tourism is treated as an export product (Euromonitor International, 2014; OECD, 2014). Thus, medical tourism was one of the priority industries promoted by the Ministry of Economy in the years 20122015, and in the years 2017-2019 with a 2022 perspective it is going to be promoted by the Polish Tourist Organisation (PTO). Creating the image of Poland as an MTD has mainly been based on the participation of medical and paramedical entities, including tourism ones, in foreign trade missions and medical tourism fairs.

PTO (2016) in a broad aspect, i.e. pro-health services, promotes inter alia medical tourism in foreign markets, constituting one of those entities which contribute to creating an image of Poland as an MTD. These actions are aimed at Russian, Ukrainian, Norwegian, American and Arabic markets, which is a result of EU subsidies. According to the PTO (2015) reports, foreign tourists expressed satisfaction with their stay in Poland. This is connected with their activities conducive to high satisfaction, among which treatments 'for health \& beauty' are of particular importance. Foreign tourists perceive Poland as: touristically attractive; offering the possibility of spending free time in line with one's 
preferences; a place which is worth further exploring, and a country which does not pose a threat to tourists. Furthermore, the country is primarily associated with cities (city break), visiting monuments, museums, forests and national parks and UNESCO sites. Yet, it is pointed out that Poland still does not have a distinctive, coherent and attractive MTD image abroad (Kiryluk \& Glińska, 2015).

While there have been studies that attempted to identify the scale of the development of MTDs in CEEC (Fetscherin \& Stephano, 2016), there have been no studies that would assess which of the MTDs in CEEC is most popular among medical tourists.

This study was an attempt to bridge this gap and therefore it puts forward another hypothesis:

H2: Poland is the country most frequently chosen by Britons and Germans who have already used or would like to use medical services in the CEEC region.

According to Buhalis (2000), each type of destination can only match certain types of demand. For that reason MTDs do not endeavor to cater for the entire market, seeing the futility of such efforts. Thus, MTD attractiveness necessitates looking at the attributes of its constitution through the prism of individual market segments. In this context, some authors indicate that demographic factors like age, gender, or nationality affect the perception of the tourism destination (e.g. Rittichainuwat, $Q u, \&$ Brown, 2001). This leads to selecting segments which attributes of MTD attractiveness will be targeted at and developing a suitable marketing strategy for each of them (Dryglas \& Salamaga, 2018). In the present study, the focus is placed especially on gender, age and nationality segmentation analysis regarded as segmentation based on socio-demographic variables. As the market of recipients of medical services offered by Poland is not a unified whole, it is crucial that local governments and MTD managers distinguish its segments based on socio-demographic factors and target particular attributes which constitute the attractiveness of Poland's MTD at a specific type of consumers in order to make MTDs in Poland more competitive on the European medical market.

Hence the attempt to demonstrate relations between particular attributes of the attractiveness of Poland's MTD market and socio-demographic factors.

Therefore, the additional research hypothesis is as follows:

H3: Respondents' opinions about Poland as a MTD are influenced by socio-demographic factors.

\section{MATERIAL AND METHODS}

The research material for the study was obtained through surveys carried out among Britons and Germans who constitute a large segment of medical tourists in Poland. They were considered the best research samples for studying Poland's identity as an MTD because studies by Lunt et al. (2014) and Hanefeld, Smith and Noree (2016) demonstrate that Poland is the leading MTD among CEECs in the case of Britons, and Schmerler (2018) reports that the same is true in the case of Germans, which stems from cross-border collaboration between providers and insurers (Ried \& Marschall, 2016). On the basis of information from Medical Tourism Association (MTA, 2015) and the International Medical Travel Journal on accredited and certified medical tourism entities those operating in Germany and Great 
Britain were selected. They were subsequently sent the Internet address of the questionnaire. An invitation to participate in the study was also made available on specially dedicated online forums and social networking sites, since as proved by Abubakar and Ilkan (2016) - virtual community membership has a strong influence on a medical tourist's behaviours and the way information is transmitted. In this way, the questionnaire was targeted at a clearly defined group of people, i.e. those who were interested in medical services provided outside their country or had already used such services and at the same time visited selected websites related to medical tourism in CEEC.

A total of 300 responses in German and English were received. Out of these, 18 questionnaires were excluded from the analysis due to incomplete information they contained. The final sample constituted $(n=282)$ valid and usable responses. In accordance with Westland's (2010) statistical algorithm for computing the absolute minimum sample size, the lower bound on sample size was established at 228 respondents. Therefore, our sample of 282 fulfills the recommended minimum sample size for sampling adequacy. For a sample size of 282 and a confidence interval of $95 \%$, the resulting sample error is $5.8 \%$. The characteristics of the target group were determined in advance. Both Britons and Germans completed the same number of surveys ( $n=141$ ), with an equal number of female and male respondents (71 vs. 70).

The study was conducted from 1 to 30 September, 2015, just after the end of the tourist season. The pilot version of the questionnaire was administered to 20 tourists to ensure that the questions were comprehensible. Their feedback and suggestions were incorporated into the final instrument.

The survey questionnaire, modified after the pilot study $(n=20)$ and based on literature review consisted of 3 questions. The first question $\left(\mathrm{Q}_{1}\right)$ was: Would you like to use medical services in CEEC? (Albania, Belarus, Bosnia and Herzegovina, Bulgaria, Croatia, the Czech Republic, Estonia, Hungary, Latvia, Lithuania, Macedonia, Moldova, Montenegro, Poland, Romania, Serbia, Slovakia, Slovenia and Ukraine - binary variable with values 1 - Yes and 0 No). The second question $\left(Q_{2}\right)$ was: Have you used medical services in CEEC? (binary variable with values 1 or 0 , measured among respondents who chose at least one country in $Q_{1}$ or $\mathrm{Q}_{2}$, the variable takes the value of 1 if a given country was indicated by the respondent and 0 otherwise). The third question $\left(\mathrm{Q}_{3}\right)$ was: What attributes do you associate Poland with? (i.e. non-medical attributes: tourism and leisure activities, big cities, historical monuments, art and culture, nature/scenery, Polish food, great shopping, friendly people, famous Poles, family/friends, developing country; medical attributes: medical services). Furthermore, with multiple-response categorical variables, each attribute was a binary response with value 1 (the attribute was indicated) or 0 (the attribute was not indicated).

In the first question, the respondents could choose a maximum of 3 CEEC. In the second question, apart from indicating 3 CEEC, the respondents could choose an answer stating that they had not had any experience with medical tourism. We also collected data on the gender, age and nationality of the respondents.

The Computer-Assisted Web Interviewing (CAWI) method was used to conduct the survey. The method was based on the technique of computer-assisted data collection. The advantage of this method is that it minimises errors by automatically saving the database and its low cost. When choosing the CAWI method, the authors largely sought to keep private space of the researched community due to the fact that medical tourists 
are a research group fairly hard to reach, given the characteristics of a postmodern society, where the Internet plays an important role in everyday life, becoming a tool for interdisciplinary research (Zając \& Batorski, 2009). The participation in this kind of study is associated with comfortable conditions, for instance the respondents can choose convenient time for filling the questionnaire. However, as indicated by Connell (2016), websites are frequently the first contact point with potential international service providers and the Internet plays a critical role on the medical tourism market.

In order to compare the probability of success of two paired variables, McNemar's exact test was used (Westfall, Troendle, \& Pennello, 2010). In order to compare the probability of success of more than two paired variables, Cochran's $Q$ test (Cochran, 1950) was used. In order to test the independence of categorical variables, Chi-square test (Satorra \& Bentler, 1994) was used. In order to test the independence of single-response categorical variable and multiple-response categorical variable, a test based on adjusted Chi-square statistic (Bilder \& Loughin, 2004) as well as the Rao-Scott second-order adjustment to Chi-square statistic and its sampling distribution were used. In order to adjust the $p$-value, the Benjamini-Hochberg method (Benjamini \& Hochberg, 1995) was applied in multiple pairwise comparisons with the use of McNemar's exact test. Simultaneously testing the set of variables regarding the independence of variables, the Bonferroni (1936) correction was used to correct $p$-value. The significance level was assumed to be 0.05 for all statistical tests.

\section{RESULTS}

In order to demonstrate that the number of people who would like to use medical services in CEEC is greater than the number of people who have already used such services in CEEC (H1), McNemar's exact test was used. Based on the test performed ( $T=116, p$ value $<0.001)$, it may be concluded that the distribution of results $\left(Q_{1}-\right.$ Yes: $93.6 \%$; $Q_{2}$ - Yes: $53.7 \%$ ) points to a greater proportion of respondents wanting to use medical services in CEEC than the proportion of respondents who have already used such services in these countries, provided that the significance level is 0.05 . With regard to Table 2 , the chi-square test of independence $(T=7.6831, \mathrm{df}=1, p$-value $<0.01)$ indicated that there is a correlation between answers to question 1 and 2 at the significance level of 0.05. Therefore, hypothesis $\mathrm{H} 1$ may be fully confirmed.

Table 2. Contingency table $Q_{1}$ vs. $Q_{2}$

\begin{tabular}{|c|c|c|c|}
\hline \multicolumn{2}{|c|}{ Contingency } & \multicolumn{2}{c|}{$\mathbf{Q}_{1}$} \\
\cline { 3 - 4 } & Yes & Yes & No \\
\hline \multirow{2}{*}{$\mathbf{Q}_{2}$} & No & 147 & 116 \\
\cline { 2 - 4 } & & 4 & 14 \\
\hline
\end{tabular}

Source: own study.

In order to verify hypotheses $\mathrm{H} 2$ and H3, Cochran's $\mathrm{Q}$ test and multiple pairwise comparisons with the use of McNemar's exact test and the Benjamini-Hochberg method were used. As for $\mathrm{H} 2$, the results of the first test $(\mathrm{T}=1442.682, \mathrm{df}=18, p$-value $<0.001)$ indicated that there exists at least one pair of countries for which probability of success differs, at 
the significance level of 0.05 . In order to determine which of the pairs differ, multiple pairwise comparisons (171) between countries $s$ and $t$, where $s \neq t$ and $s, t=1, \ldots, 19$ were conducted using McNemar's exact test as well as the Benjamini-Hochberg method as adjustment methods for $p$-value. In 108 cases out of 171, the null hypothesis was rejected at the significance level of 0.05 . This means that there are 108 pairs of countries for which probability of success differs. In particular, Poland compared to every other country, belongs to this group with the smallest adjusted p-values. Table 3 presents the first 20 pairs out of 108 in ascending order by adjusted $p$-value. Thus, it may be concluded that the percentage of answers pertaining to the country most frequently chosen by tourists who have already used or would like to use medical services in CEEC is the highest for Poland (83.5\%), and the results of the statistical tests performed indicate that it is also significantly different from the other values, which confirms $\mathrm{H} 2$.

Table 3. The first 20 pairs of countries with different probability of success

\begin{tabular}{|l|c|}
\hline \multicolumn{1}{|c|}{ Comparison } & p.adjust \\
\hline Bosnia and Herzegovina - Poland & $2.03 \mathrm{E}-64$ \\
\hline Poland - Ukraine & $4.06 \mathrm{E}-64$ \\
\hline Macedonia - Poland & $9.52 \mathrm{E}-64$ \\
\hline Belarus - Poland & $5.64 \mathrm{E}-63$ \\
\hline Albania - Poland & $4.75 \mathrm{E}-60$ \\
\hline Latvia - Poland & $1.54 \mathrm{E}-59$ \\
\hline Moldova - Poland & $8.40 \mathrm{E}-59$ \\
\hline Montenegro - Poland & $8.40 \mathrm{E}-59$ \\
\hline Poland - Serbia & $1.46 \mathrm{E}-58$ \\
\hline Lithuania - Poland & $1.00 \mathrm{E}-57$ \\
\hline Croatia - Poland & $1.73 \mathrm{E}-43$ \\
\hline Estonia - Poland & $3.88 \mathrm{E}-43$ \\
\hline Poland - Slovenia & $2.88 \mathrm{E}-42$ \\
\hline Bulgaria - Poland & $4.23 \mathrm{E}-41$ \\
\hline Poland - the Czech Republic & $3.28 \mathrm{E}-37$ \\
\hline Poland - Romania & $2.71 \mathrm{E}-35$ \\
\hline Poland - Slovakia & $7.23 \mathrm{E}-35$ \\
\hline Hungary - Poland & $5.49 \mathrm{E}-34$ \\
\hline Macedonia - the Czech Republic & $2.44 \mathrm{E}-19$ \\
\hline Macedonia - Slovakia & $2.64 \mathrm{E}-19$ \\
\hline
\end{tabular}

Source: own study.

In order to verify $\mathrm{H} 3$, a test for independence between single-response categorical variable $\mathrm{X}$ and multiple-response categorical variable $\mathrm{Y}$ was used based on the Rao-Scott second-order adjustment to the Pearson statistic and its sampling distribution.

Based on the results of the statistical test performed (T.adj $=9.25, \mathrm{df} . \mathrm{adj}=9.67, p$.adj $=0.4775 ; \mathrm{T} \cdot \mathrm{adj}=80.62, \mathrm{df} \cdot \mathrm{adj}=34.67, p \cdot \mathrm{adj}<0.0001 ; \mathrm{T} \cdot \mathrm{adj}=122.6, \mathrm{df} \cdot \mathrm{adj}=10.64, p \cdot \mathrm{adj}<$ 0.0001 ), it may be concluded that since $p$-value $>0.05$, respectively: gender does not influence the choice of attributes and age and nationality influence the choice of attributes. In order to simultaneously test a set of variables included in $\mathrm{H} 3$ the Bonferroni correction was applied. The following $p$-values were obtained: $1.0000,0.0000,0.0000$. Therefore, respondents' opinions do not depend on gender, but depend on age and nationality. Thus, 
it may be concluded that in light of the values presented in Table 4 and the results of the statistical test performed, hypothesis H3 may be partially confirmed.

\section{CONCLUSIONS AND DISCUSSION}

The results of the present empirical study indicate that tourists from Western Europe are currently more interested in using medical services in Poland than in the past. This is due to the involvement of respective governments in the development of medical tourism of the countries concerned (Ganguli \& Ebrahim, 2017). Recently, medical tourism has become a part of the policy of governments in CEEC, among them Montenegro and Poland. Its objective is not only an effective intervention in the national healthcare system or an increase in exports of medical services, but also an improvement of a poor image of MTD (Ormond, 2011). Good practices of governments include the support and creation of MTD image (Jónás-Berki, Csapó, Pálfi, \& Aubert, 2015). They are primarily based on: incentives, government promotion and policy investments (Kowalska-Bobko, Mokrzycka, Sagan, Włodarczyk, \& Zabdyr-Jamróz, 2016). Additionally, they encourage cooperation and partnerships between the public and private medical and tourism sectors (lordache, Ciochină, \& Popa, 2013).

Out of CEEC, Poland was the most frequently chosen MTD because in Poland costs of healthcare services are often lower than in the countries of Western Europe, and the standard of these services is considered to be high (Euromonitor International, 2014). What is also worth emphasising is the fact that associations with a given destination are affected by such socio-demographic factors as age and nationality but not gender, which may stem from the fact that awareness and national identity play a greater role when choosing attributes defining an MTD. So, the concept of building MTD attractiveness is the result of not only specific features of an MTD, which determine its market success, but also, to a large extent, of how the medical tourists perceive a given MTD.

The added value of the present work, which contributes to the development of marketing in MTDs, encompasses the cognitive (empirical) and applied dimensions. As regards the empirical part, identification of the growing importance of Poland as a MTD, as well as the socio-demographic factors affecting the choice of a given MTD can be a useful tool for marketing planners, destination managers and marketers to create an effective marketing policy of MTDs. This approach implies collaborative, cooperative and multilevel way of MTD management. In other words, the managers of the supply-side entities providing medical tourism services and destination management organisations should be an active nexus between different actors involved in enterprise and destination management, planning and policy making. Consequently, what is necessary to create the attractiveness of MTDs in Poland is cooperation at the national level, regional level (between individual regions) and local level (between local authorities and medical and tourist enterprises as well as collaboration of medical and tourism companies).

Due to time and financial limitations of the project, the empirical research was conducted only in reference to selected medical tourists. The obstacles mentioned do not diminish the cognitive value of the research. They constitute a starting point for further research studies, which should be aiming especially at a deeper exploration of MTD attractiveness in Poland. This study was limited by the methodology applied as outlined below. 
Table 4. Value distribution by gender, age, and nationality

\begin{tabular}{|c|c|c|c|c|c|c|c|c|c|c|c|c|c|c|c|c|c|c|c|c|c|c|c|}
\hline \multirow{2}{*}{\multicolumn{2}{|c|}{ Category }} & \multicolumn{2}{|c|}{ 톨 } & \multicolumn{2}{|c|}{ 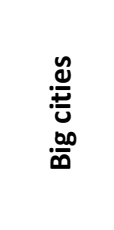 } & \multicolumn{2}{|c|}{ 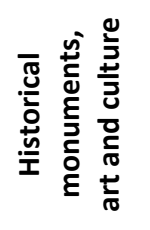 } & \multicolumn{2}{|c|}{ 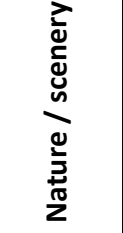 } & \multicolumn{2}{|c|}{$\begin{array}{l}8 \\
8 \\
\frac{0}{4} \\
\frac{1}{n} \\
\frac{-0}{0} \\
0\end{array}$} & \multicolumn{2}{|c|}{ 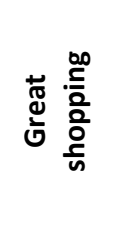 } & \multicolumn{2}{|c|}{ 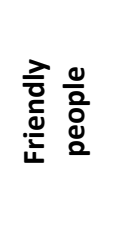 } & \multicolumn{2}{|c|}{$\underset{\frac{n}{\tilde{L}}}{\stackrel{n}{0}} \frac{n}{0}$} & \multicolumn{2}{|l|}{ 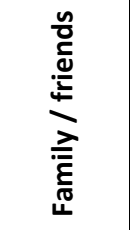 } & \multicolumn{2}{|c|}{ 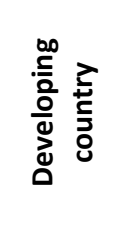 } & \multicolumn{2}{|c|}{ 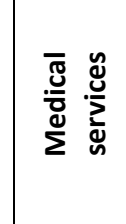 } \\
\hline & & 0 & 1 & 0 & 1 & 0 & 1 & 0 & 1 & 0 & 1 & 0 & 1 & 0 & 1 & 0 & 1 & 0 & 1 & 0 & 1 & 0 & 1 \\
\hline \multirow{2}{*}{ Gender } & male & 116 & 23 & 85 & 54 & 119 & 20 & 121 & 18 & 95 & 44 & 122 & 17 & 105 & 34 & 91 & 48 & 127 & 12 & 126 & 13 & 78 & 61 \\
\hline & female & 119 & 23 & 89 & 53 & 112 & 30 & 119 & 23 & 102 & 40 & 119 & 23 & 98 & 44 & 99 & 43 & 133 & 9 & 136 & 6 & 72 & 70 \\
\hline \multirow{5}{*}{ Age } & $18-29$ & 42 & 7 & 21 & 28 & 42 & 7 & 44 & 5 & 37 & 12 & 37 & 12 & 39 & 10 & 33 & 16 & 39 & 10 & 44 & 5 & 34 & 15 \\
\hline & 30-39 & 42 & 15 & 40 & 17 & 46 & 11 & 49 & 8 & 36 & 21 & 48 & 9 & 40 & 17 & 37 & 20 & 56 & 1 & 55 & 2 & 34 & 23 \\
\hline & $40-49$ & 49 & 16 & 42 & 23 & 52 & 13 & 51 & 14 & 44 & 21 & 56 & 9 & 51 & 14 & 53 & 12 & 63 & 2 & 61 & 4 & 33 & 32 \\
\hline & $50-59$ & 58 & 3 & 38 & 23 & 49 & 12 & 53 & 8 & 48 & 13 & 53 & 8 & 33 & 28 & 40 & 21 & 60 & 1 & 56 & 5 & 29 & 32 \\
\hline & $\geq 60$ & 44 & 5 & 33 & 16 & 42 & 7 & 43 & 6 & 32 & 17 & 47 & 2 & 40 & 9 & 27 & 22 & 42 & 7 & 46 & 3 & 20 & 29 \\
\hline \multirow{2}{*}{ Nationality } & German & 128 & 12 & 70 & 70 & 133 & 7 & 121 & 19 & 95 & 45 & 126 & 14 & 121 & 19 & 77 & 63 & 122 & 18 & 129 & 11 & 71 & 69 \\
\hline & British & 107 & 34 & 104 & 37 & 98 & 43 & 119 & 22 & 102 & 39 & 115 & 26 & 82 & 59 & 113 & 28 & 138 & 3 & 133 & 8 & 79 & 62 \\
\hline
\end{tabular}

Notes: 0 - attribute was not chosen, 1 - attribute waschosen

Source: own study. 
The CAWI method has some disadvantages. A lot of people still do not have Internet access, although various studies suggest that electronic word-of-mouth is now the most common source of information to medical travellers.

\section{REFERENCES}

Abubakar, A.M., \& Ilkan, M. (2016). Impact of online WOM on destination trust and intention to travel: A medical tourism perspective. Journal of Destination Marketing \& Management, 5(3), 192-201. https://doi.org/10.1016/j.jdmm.2015.12.005

Beladi, H., Chao, C.-C., Ee, M.S., \& Hollas, D. (2015). Medical tourism and health worker migration in developing countries. Economic Modelling, 46, 391-396. https://doi.org/10.1016/j.econmod.2014.12.045

Benjamini, Y., \& Hochberg, Y. (1995). Controlling the false discovery rate: A practical and powerful approach to multiple testing. Journal of the Royal Statistical Society, Series B, 57(1), 289-300.

Bilder, C.R., \& Loughin, T.M. (2004). Testing for marginal independence between two categorical variables with multiple responses. Biometrics, 60(1), 241-248.

Bonferroni, C.E. (1936). Teoria statistica delle classi e calcolo delle probabilità. Pubblicazioni del $R$ Istituto Superiore di Scienze Economiche e Commerciali di Firenze, 8, 3-62.

Borek, E. (2013). Medical tourism in Europe and in Poland - present status, development bariers, perspectives and recemendations concerning the development of medical tourism in Poland. Public Health and Governance. Scientific Issues of Health Protection, 11, 333-348.

Breitrück, V., \& Nunn, E. (2011). Health \& medical tourism. in A. Papathanassis, (Ed.). The long tail of tourism: holiday niches and their impact on mainstream tourism (pp. 57-67). Wiesbaden: Gabler Verlag.

Buhalis, D. (2000). Marketing the competitive destination of the future. Tourism Management, 21(1), 97-116. https://doi.org/10.1016/S0261-5177(99)00095-3

Cameron, K., Crooks, V.A., Chouinard, V., Snyder, J., Johnston, R., \& Casey, V. (2014). Motivation, justification, normalization: Talk strategies used by Canadian medical tourists regarding their choices to go abroad for hip and knee surgeries. Social Science \& Medicine, 106, 93-100. https://doi.org/10.1016/j.socscimed.2014.01.047

Casey, V., Crooks, V.A., Snyder, J., \& Turner, L. (2013). Knowledge brokers, companions, and navigators: a qualitative examination of informal caregivers' roles in medical tourism. International Journal for Equity in Health, 12, 94. https://doi.org/10.1186/1475-9276-12-94

Chew, Y.T., \& Koeshendro, A.D. (2015). Identifying research gaps in medical tourism. In M. Kozak, N. \& Kozak (Eds.). Destination marketing: An international perspective (pp. 119-125). London: Taylor \& Francis.

Choi, H. (2016). Medical tourism. In J. Jafari \& H. Xiao (Eds.). Encyclopedia of tourism (pp. 602-603). Switzerland: Springer International Publishing.

Cochran W.G. (1950). The comparison of percentages in matched samples. Biometrika, 37(3-4), 256-266.

Connell, J. (2013). Contemporary medical tourism: Conceptualisation, culture and commodification. Tourism Management, 34, 1-13. https://doi.org/10.1016/j.tourman.2012.05.009

Connell, J. (2016). Reducing the scale? From global images to border crossings in medical tourism. Global Networks, 16(4), 531-550. https://doi.org/10.1111/glob.12136

Crooks, V.A., Turner, L., Snyder, J., Johnston, R., \& Kingsbury, P. (2011). Promoting medical tourism to India: Messages, images, and the marketing of international patient travel. Social Science \& Medicine, 72(5), 726-732. https://doi.org/10.1016/j.socscimed.2010.12.022 
de la Hoz-Correa, A., Muñoz-Leiva, F., \& Bakucz, M. (2018). Past themes and future trends in medical tourism research: A co-word analysis. Tourism Management, 65, 200-211. https://doi.org/10.1016/j.tourman.2017.10.001

Dryglas, D. (2018). Designing a health tourism product structure model in the process of marketing management. Warsaw: PWN.

Dryglas, D., \& Salamaga, M. (2017). Applying destination attribute segmentation to health tourists: A case study of Polish spa resorts. Journal of Travel \& Tourism Marketing, 34(4), 503-514. https://doi.org/10.1080/10548408.2016.1193102

Dryglas, D., \& Salamaga, M. (2018). Segmentation by push motives in health tourism destinations: A case study of Polish spa resorts. Journal of Destination Marketing \& Management, 9, 234-246. https://doi.org/10.1016/j.jdmm.2018.01.008

Ebrahim, A.H., \& Ganguli, S. (2017). Strategic priorities for exploiting Bahrain's medical tourism potential. Journal of Place Management and Development, 10(1), 45-60. https://doi.org/10.1108/JPMD-03-2016-0011

Euromonitor International (2014). Health and wellness tourism in Poland. Retrieved on January 5, 2019 from http://www.euromonitor.com/health-and-wellness-tourism-in-poland/report

Fetscherin, M., \& Stephano, R.M. (2016). The medical tourism index: Scale development and validation. Tourism Management, 52, 539-556. https://doi.org/10.1016/j.tourman.2015.08.010

Freyer, W., \& Kim, B.S. (2014). Medizintourismus und Medizinreisen - eine inter-disziplinäre Betrachtung. Gesundheitswesen, 76(1), 65-68.

Gallarza, M.G., Saura, I.G., \& Garcia, H.C. (2002). Destination image: Toward a conceptual framework. Annals of Tourism Research, 29(1), 56-78. https://doi.org/10.1016/S0160-7383(01)00031-7

Ganguli, S., \& Ebrahim, A.H. (2017). A qualitative analysis of Singapore's medical tourism competitiveness. Tourism Management Perspectives, 21, 74-84. https://doi.org/10.1016/j.tmp.2016.12.002

Ghanbari, S., Hajinejad, A., \& Rahmani, P. (2014). Formulating strategic plan of medical tourism development. International Journal of Travel Medicine and Global Health, 2(4), 149-154.

Guiry, M., \& Veguist, D.G. (2015). South Korea's medical tourism destination brand personality and the influence of personal values. Asia Pacific Journal of Tourism Research, 20(5), 563-584. https://doi.org/10.1080/10941665.2014.904804

Gupte, G., \& Panjamapirom, A. (2014). Understanding medical tourism. In A.I. Culyer (Ed.), Encyclopedia of Health Economics (pp. 404-410). York, UK: Elsevier.

Hanefeld, J., Smith, R., \& Noree, T. (2016). Medical tourism. In R.M. Scheffler. (Ed.), World scientific handbook of global health economics and public policy (pp. 333-350). London: World Scientific Publishing Co.

Hemdi, M.A., Hassan, N.A., Aminuddin, N., \& Adanan, A. (2016). Medical tourism destination choice: A proposition and research agenda. In S.A. Jamal, S.M.Radzi,., N. Sumarjan, C.T, Chik, \& M.F.S. Bakhtiar,. (Eds.), Innovation and best practices in hospitality and tourism research (pp. 185-188). London: Taylor \& Francis Group.

Heung, V.C.S., Kucukusta, D., \& Song, H. (2010). A conceptual model of medical tourism: Implications for future research. Journal of Travel \& Tourism Marketing, 27(3), 236-251. https://doi.org/10.1080/10548401003744677

Hopkins, L., Labonte, R., Runnels, V., \& Packer, C. (2010). Medical tourism today: What is the state of existing knowledge?. Journal of Public Health Policy, 31(2), 185-198. https://doi.org/10.1057/jphp.2010.10

Idrus, S., Musa, R., Naziman, Y.H.N.M., Aznan, N.F.M., Othman, A.Y., \& Pauzi, N.M. (2012). Medical tourism destination brand positioning model. In A. Zainal, S.M. Radzi, R., Hashim, C.T. Chik, \& R. 
Abu, (Eds.), Current issues in hospitality and tourism research and innovations. Proceedings of the International Hospitality and Tourism Conference, IHTC 2012 (pp. 515-518). Boca Raton: CRC Press, Taylor \& Francis Group.

Iordache, C., Ciochină, I., \& Popa, R. (2013). Medical tourism - between the content and socioeconomic development goals. Development strategies. Romanian Journal of Marketing, 1, 31-42.

Johnston, R., Crooks, V.A., Snyder, J., \& Kingsbury, P. (2010). What is known about the effects of medical tourism in destination and departure countries? A scoping review. International Journal for Equity in Health, 9, 24. https://doi.org/10.1186/1475-9276-9-24

Jónás-Berki, M., Csapó, J., Pálfi, A., \& Aubert, A. (2015). A market and spatial perspective of health tourism destinations: The Hungarian experience. International Journal of Tourism Research, 17, 602-612.

Junio, M.M.V., Kim, J.H., \& Lee, T.J. (2017). Competitiveness attributes of a medical tourism destination: The case of South Korea with importance-performance analysis. Journal of Travel \& Tourism Marketing, 34(4), 444-460. https://doi.org/10.1080/10548408.2016.1182454

Kiryluk, H., \& Glińska, E. (2015). Creation and evaluation of the tourist image of a country - The example of Poland. Procedia - Social and Behavioral Sciences, 213, 671-676.

Kiss, K. (2015). The challenges of developing health tourism in the Balkans. Tourism, 63(1), 97-110.

Koggalage, P.D., Gunawardena, N.S., \& de Silva, A.H. (2017). Medical travellers' perspectives in selecting in-patient services at selected private hospitals in Sri Lanka. Asia Pacific Journal of Tourism Research, 22(7), 747-757. https://doi.org/10.1080/10941665.2017.1319396

Kowalska-Bobko, I., Mokrzycka, A., Sagan, A., Włodarczyk, W.C., \& Zabdyr-Jamróz, M. (2016). Implementation of the cross-border healthcare directive in Poland: How not to encourage patients to seek care abroad?. Health Policy, 120(11), 1233-1239. https://doi.org/10.1016/j.healthpol.2016.07.011

Lu, H.Y., \& Wu, W.Y. (2018). Factors associated with medical travel behaviours: The input-process-output perspective. Current Issues in Tourism, 21(3), 243-258. https://doi.org/10.1080/13683500.2015.1072503

Lubowiecki-Vikuk, A. (2018). Consumption of dental services: Medical tourism in CEE. European Journal of Service Management, 27/1(3), 135-142. https://doi.org/10.18276/ejsm.2018.27/1-16

Lubowiecki-Vikuk, A., \& Gnusowski, M. (2016). The role of inter-cultural competence on the medical tourism market in Poland. Hygeia Public Health, 51(3), 255-261.

Lubowiecki-Vikuk, A., \& Kurkowiak, J. (2017). Medical tourism potential of Central and Eastern Europe: Attempt at classification. CBU International Conference Proceedings, 5, 286-293. https://doi.org/10.12955/cbup.v5.940

Lubowiecki-Vikuk, A., \& Mucha, D. (2015). Pharmaceutical tourism development prospects in the region of Southern Poland. Scientific Treatises of University School of Physical Education in Wrocław, 49, 147-156.

Lubowiecki-Vikuk, A., \& Rab-Przybyłowicz, J. (2015). Selected aspect of functioning medical tourism market in Poland. Folia Turistica, 34, 85-107.

Lunt, N., Smith, R.D., Mannion, R., Green, S.T., Exworthy, M., Hanefeld, J., \& et al. (2014). Implications for the NHS of inward and outward medical tourism: A policy and economic analysis using literature review and mixed-methods approaches. Health Services and Delivery Research, 2(2), 1-234.

Mahendradhata, Y. (2019). Proceed with caution: Potential challenges and risks of developing healthcare tourism in Indonesia. Global Public Health, 14(3), 340-350. https://doi.org/10.1080/17441692.2018.1504224 
Mainil, T., Eijgelaar, E., Klijs, J., Nawijn, J., \& Peeters, P. (2017). Research for TRAN Committee Health tourism in the EU: a general investigation. Brussels: European Parliament, Policy Department for Structural and Cohesion Policies.

Mayo, E., \& Jarvis, L. (1981). Psychology of leisure travel. Boston: CABI Publishing.

MTA (2015). MTA members in Europe. Retrieved from: https://www.medicaltourismassociation.com/ en/mta-members-in-europe.html

OECD (2014). Health at a glance: Europe 2014. OECD Publishing.

Ormond, M., \& Kaspar, H. (2019). Medical travel/tourism and the city. In I.Vojnovic, A.L. Pearson, A. Gershim, G. DeVerteuil \& A. Allen (Eds.), Handbook of Global Urban Health (pp. 1-21). Abingdon: Routledge.

Ormond, M. (2011). Shifting subjects of health-care: Placing 'medical tourism' in the context of Malaysian domestic health-care reform. Asia Pacific Viewpoint, 52(3), 247-259. https://doi.org/10.1111/j.1467-8373.2011.01457.x

Ormond, M., \& Sulianti, D. (2017). More than medical tourism: lessons from Indonesia and Malaysia on South-South intra-regional medical travel. Current Issues in Tourism, 20(1), 94-110. https://doi.org/10.1080/13683500.2014.937324

Ormond, M., Wong, K.M., \& Chan, C.K. (2014). Medical tourism in Malaysia: how can we better identify and manage its advantages and disadvantages?. Global Health Action, 7, 96-99. https://doi.org/10.3402/gha.v7.25201

Pollard, K. (2012). How can we measure a destination's attractiveness?. Retrieved from https://www.imtj.com/blog/how-can-we-measure-destinations-attractiveness/ on January 5, 2019.

Prebensen, N.K. (2007). Exploring tourists' images of a distant destination. Tourism Management, 28(3), 747-756. https://doi.org/10.1016/j.tourman.2006.05.005

PTO. (2015). A tourism service consumer survey, assessing the level of satisfaction with tourism services used by national and foreign tourists during their travel and stay in Poland in 2014. Retrieved from http://www.pot.gov.pl/do-pobrania/l/materialy-do-pobrania/badania-i-analizy on January 5, 2019.

PTO. (2016). Market analysis - health service promotion. Retrieved from http://pot.gov.pl/64 fundusze-ue/l/program-promocji-uslug-prozdrowotnych/koncepcja-programu-promocjiuslug-prozdrowotnych on January 5, 2019.

Rab-Przybyłowicz, J. (2016). Trends and socio-economic aspects of medical tourism development in Poland. Studia Periegetica, 2(16), 99-118.

Ried, W., \& Marschall, P. (2016). Potential benefits of cross-border health care: The case of Poland and Germany. Economics and Sociology, 9(3), 14-27. https://doi.org/10.14254/2071789X.2016/9-3/2

Rittichainuwat, B.N., Qu, H., \& Brown, T.J. (2001). Thailand's international travel image mostly favorable. Cornell Hospitality Quarterly, 42(2), 82-95. https://doi.org/10.1016/S00108804(01)80020-3

Runnels, V., \& Carrera, P. (2012). Why do patients engage in medical tourism?. Maturitas, 73(4), 300304. https://doi.org/10.1016/j.maturitas.2012.08.011

Satorra, A., \& Bentler, P.M. (1994). Corrections to test statistics and standard errors in covariance structure analysis. In von A. Eye \& C.C. Clogg (Eds.), Latent variables analysis: Applications for developmental research (pp. 399-419). Thousand Oaks, CA: Sage.

Schmerler, K. (2018). Medical tourism in Germany: Determinants of international patients' destination choice. Cham, Switzerland: Springer International Publishing. 
Smith, M., \& Puczkó, L. (2014). Health, tourism and hospitality: wellness, spas and medical travel. London: Routledge.

Smith, M., Puczkó, L., Michalkó, G., Kiss, K., \& Sziva, I. (2016). Balkan wellbeing and health tourism study. Budapest: Metropolitan University. Retrieved from http://infota.org/wp-content/uploads/2016/03/BalkanWellbeingFINALREPORT.pdf on January 5, 2019.

South Korea medical tourism market: Insights, opportunity, analysis, market shares and forecast 2017-2022. (2018). Retrieved from http://www.orbisresearch.com/reports/index/ southkorea-medical-tourism-market-insights-opportunity-analysis-market-shares-and-forecast2017-2022 on January 5, 2019.

Stankova, M., Tsvetkov, T., \& Ivanova, L. (2019). Tourist development between security and terrorism: empirical evidence from Europe and the United States. Oeconomia Copernicana, 10(2). https://doi.org/10.24136/oc.2019.011

Sziva, I., Balázs, O., Michalkó, G., Kiss, K., Puczkó, L., Smith, M., \& Apró, E. (2017). Branding strategy of the countries in the Balkan region - focusing on health tourism. GeoJournal of Tourism and Geosites, 19, 61-69.

Tasci, A.D.A., Gartner, W.C., \& Cavusgil, S.T. (2007). Conceptualization and operationalization of destination image. Journal of Hospitality \& Tourism Research, 31(2), 194-223. https://doi.org/10.1177/1096348006297290

Tham, A. (2018). Sand, surgery and stakeholders: A multi-stakeholder involvement model of domestic medical tourism for Australia's Sunshine Coast. Tourism Management Perspectives, 25, 2940. https://doi.org/10.1016/j.tmp.2017.11.002

UNWTO (2007). A practical guide to tourism destination management. Madrid: World Tourism Organization.

Wang, H.Y. (2012). Value as a medical tourism driver. Managing Service Quality, 22(5), 465-491. https://doi.org/10.1108/09604521211281387

Westfall, P.H., Troendle, J.F., \& Pennello, G. (2010). Multiple McNemar tests. Biometrics, 66(4), 1185-1191.

Westland, J.C. (2010). Lower bounds on sample size in structural equation modeling. Electronic Commerce Research and Applications, 9(6), 476-487.

Wisla, R., \& Sierotowicz, T. (2016). Medical technological specializations of Central and Eastern European regions. Economics and Sociology, 9, 195-209. https://doi.org/10.14254/2071789X.2016/9-3/17

Wongkit, M., \& McKercher, B. (2016). Desired attributes of medical treatment and medical service providers: A case study of medical tourism in Thailand. Journal of Travel \& Tourism Marketing, 33(1), 14-27. https://doi.org/10.1080/10548408.2015.1024911

Zając, J.M., \& Batorski, D. (2009). Methods of increasing maneuverability in the Internet research. In A. Haber \& M. Szałas (Eds.). Evaluation to the challenges facing the public finance sector (pp. 129-147). Warsaw: PARP.

Zarei, A., \& Maleki, F. (2019). Asian medical marketing, a review of factors affecting Asian medical tourism development. Journal of Quality Assurance in Hospitality \& Tourism, 20(1), 1-15. https://doi.org/10.1080/1528008X.2018.1438959

Zhang, J., Seo, S., \& Lee, H. (2013). The impact of psychological distance on Chinese customers when selecting an international healthcare service country. Tourism Management, 35, 32-40. https://doi.org/10.1016/j.tourman.2012.05.007 


\section{Authors}

Contribution share of authors is equal and amounted to $50 \%$ each of them: D. Dryglas - contributed to the discussion, and performed the statistical analyses; A. Lubowiecki-Vikuk - conceived the study, designed the study, collected data and drafted the manuscript.

\section{Diana Dryglas}

Associate Professor at the Department of General Geology and Geotourism of the AGH University of Science and Technology. Her research interests include management of a tourism product and tourism destination, and health tourism, especially therapeutic (healing) tourism.

Correspondence to: Dr hab. Diana Dryglas, AGH University of Science and Technology, Department of General Geology and Geotourism, Al. Mickiewicza, 30, 30-059 Krakow, Poland, e-mail: ddryglas@agh.edu.pl

ORCID (1) http://orcid.org/0000-0001-6136-1369

\section{Adrian Lubowiecki-Vikuk}

Assistant Professor at the Department of Consumer Behaviour Research of the Warsaw School of Economics. His research interests include consumer behaviour in the area of sport, tourism and medicine.

Correspondence to: Dr Adrian Lubowiecki-Vikuk, Warsaw School of Economics, Institute of Management, Department of Consumer Behaviour Research, Al. Niepodległości, 162, 02-554 Warsaw, Poland, e-mail: adrian.lubowiecki-vikuk@sgh.waw.pl

ORCID (1) http://orcid.org/0000-0001-9672-9514

\section{Acknowledgements and Financial Disclosure}

This research was supported by AGH University of Science and Technology in Krakow grant No. 11.11.140.005.

We gratefully acknowledge the efforts of two anonymous reviewers for valuable comments on this article.

\section{Copyright and License}

This article is published under the terms of the Creative Commons

Attribution - NoDerivs (CC BY-ND 4.0) License

http://creativecommons.org/licenses/by-nd/4.0/

Published by the Centre for Strategic and International Entrepreneurship - Krakow, Poland 